\title{
QUESTIONING THE SMALL-CLAIMS COURT IN INDONESIA IN THE FRAMEWORK OF NATIONAL CIVIL PROCEDURAL LAW REFORM ${ }^{\Omega}$
}

\author{
Anita Afriana and Isis Ikhwansyah \\ Fakultas Hukum Universitas Padjadjaran \\ E-mail: nie782003@yahoo.com
}

\begin{abstract}
One of the alternatives to renew the law is by forming regulations and the litigation institutions that can accommodate the society. In private litigation proceeding, manifestation of ideas in litigation reform can be seen through by the Supreme Court Regulation (PerMA) No. 2 Year 2015. This fast procedural mechanism is called small claims court (SCC). This article discusses the effectiveness of SCC implementation in Indonesia as one of the states that enacts civil law system, and its regulation in order to renew civil law procedures. Research methodology used juridical-normative while the results show that SCC is effectively enacted in Indonesia. The prevailing regulation currently in PerMA is to fill the gap of law, considering that the legislation process takes time to establish an act. Thus, it is best for Indonesia to establish SCC within a certain act in the future, to pursue the unification of law within the regime of private law procedures.
\end{abstract}

Keywords: effectiveness, civil law, small-claims court, renewal of law

\begin{abstract}
Abstrak
Pembangunan hukum dilakukan antara lain melalui reaktualisasi hukum (undang-undang) dan reformasi peradilan sebagai bagian dari kelembagaan hukum. Salah satu wujud pembangunan hukum acara perdata adalah berlakunya PerMA No. 2 Tahun 2015 tentang penyelesaian gugatan sederhana. Mekanisme penyelesaian gugatan sederhana dikenal sebagai Small Claims Court (SCC), yang mana mekanisme ini telah diterapkan baik pada negara dengan sistem civil law maupun common law. Dengan pendekatan yuridis normatif, artikel ini membahas SCC di Indonesia sebagaimana yang diatur dalam PerMa No 2 Tahun 2015 dan konsep pengaturan SCC dalam rangka pembaharuan hukum acara perdata nasional. Dewasa ini sistem hukum tidak diterapkan secara murni, begitu pula di Indonesia dengan sistem civil law mengadopsi SCC yang berasal dari sistem common law, selanjutnya diterapkan dalam PerMA No. 2 Tahun 2015. Pengaturan saat ini dalam PerMA dimaksudkan untuk mengisi kekosongan hukum, namun dimasa akan datang diharapkan SCC terintegrasi dalam undang-undang hukum acara perdata agar tercapainya unifikasi hukum acara perdata di Indonesia.
\end{abstract}

Kata kunci: efektivitas, civil law, gugatan sederhana, pembaharuan hukum

\section{Introduction}

Law development must be done thoroughly regarding its complementary. Law system is a complex organization which interacts among structure, substance and culture. The legal structure means judicial, substance means rules, and culture means a common culture and customs.

In the context of legal structure, duties or functions of the judiciary charged to court.

This article is part of Grant of Doctoral Dissertation Research, funded by Ministry of Research, Technology and Higher Edu-cation No: 021/SP2H/LT/DRPM/I/2016.
The court is an organ or body that perform tasks or functions of the judiciary. The task of the judiciary is to examine, adjudicate and also resolve any matter referred to it, based on Article 2 (4) of Law Number 48 Year 2009 on Judicial Authority stating that the judiciary is simple, fast, and low cost conducted.

Practically, the procedures for settling disputes in the court through litigation stage is a formal stage that must be passed by litigants. In implementation, the stages of litigation is the cause of resolving disputes length through the courts, besides parties presence and domicile 
factor. For the parties who filed the lawsuit with a small value, the length of proceedings to obtain a judgment is not proportional to the lawsuit be charged. In the end, judicial institutions in charge of enforcing the law and justice when receive, examine, and resolve any disputes submitted are considered as a ineffective and inefficient place to resolve disputes. However, settlement of disputes through formal court will produce a decision that gives legal assurance. This is different from the settlement of disputes through the mechanism outside the court that is relatively quick, but in certain situ-ations they need a court warrant to be executed.

Rapid settlement of civil disputes in the District Court is urgently needed in Indonesia, considering a lot number of people in Indonesia which tend to have potentially high dispute. On the other hand, the settlement through mediation is proved unsuccessful even it causes longer proceedings ${ }^{1}$. Therefore, development of legal relations in economic and other civil society requires simpler, faster and low-cost procedures for settling disputes, especially in a small legal relationship. As a result, on August 7, 2015 the Supreme Court issued Supreme Court Regulation Number 2 of 2015 concerning Procedures for Lawsuit of Small-Claims Court.

Procedures for Lawsuit of Small-Claims Court had actually already applied in some countries referred as the Small Claims Court (hereinafter referred to as SCC). This procedure was firstly introduced in Australia then well-developed countries, primarily in the common law system like the United States and Singapore. SCC Model of dispute settlement is a dispute resolution system that is simple, with a single judge, without a jury, and the proof is simple.

Before 2015, the procedures for settling disputes through the District Court is not based on the amount of value cases. Therefore, even if there is a small claim to the value of cases, the settlement process should be based on the

R. Benny Riyanto, "Remodelling and Repositioning of Court's Mediation in Indonesia, Diponegoro Law Review, Vol 1 No. 1, Oktober 2016, Semarang: Faculty of Law, Universitas Diponegoro, page 28. provisions of the Civil Procedural Law. When Plaintiffs or their attorneys filed a petition for the first time at the secretariat, there was no difference in procedure based on the value of the lawsuit. Thus, for the party who filed the lawsuit with the small value material is unfair if it has to undergo a series of complicated stages proceedings that must be passed to obtain a court ruling provides legal assurance, on the other hand, enforcing the law should also consider the benefits and fair law enforcement.

Some types of civil disputes, especially disputes with the small value of the material loss requires fast and simple completion but it still requires a binding legal effect from the settlement proceeds in the form of the judge's decision. Therefore, the SCC concept was issued at common law system adopted in Indonesia and used to settle small claims. Quoting the statement of Erman Rajagukguk which states that globalization will lead to regulation of developing countries regarding investment, trade and services economic sector approach developed countries (convergency) ${ }^{2}$, hence, today is not only in economic law but also procedural law; there is a strong influence of the common law system.

The procedure of settling small claims as set up in Supreme Court Regulation Number 2 Year 2015 has a different judicial procedure as set up in HIR/ RBg as a positive civil procedural law. Referring to the existing theory, there are at least five (5) roles from the Supreme Court Rules in fulfilling the needs of state administration especially in the the judicial sector, namely: first as a stopgap law; second, supplementary provisions of the law is less clear in arranging any thing related to procedural law; Third, the Supreme Court Regulation as a means of law discovery; fourth, as a means of law enforcement, and the fifth, the Supreme Court Regulation as a source of law for the legal community, especially the judges in addressing the technical difficulties application of procedural

\footnotetext{
Erman Rajagukguk, "Peranan Hukum dalam Pembangunan Pada Era Globalisasi", Jurnal Hukum Bisnis, Vol. 6 No. II, Jakarta: Yayasan Pengembangan Hukum Bisnis, page 114 .
} 
law that was already no longer relevant to the current status. $^{3}$

The existence of Supreme Court Regulation No. 2 of 2015 is in accordance with the needs of people seeking justice, as a temporary solution to get around yet enactment of the national civil procedural law in order to avoid a legal vacuum. This is in line with the opinion of Mochtar Kusumaatmadja which states that adequate law does not regard the law as a set of rules and principles that regulate human life in society but it should also include the institution and process needed to realize law is in reality of the society.

\section{Problems}

The problems formulated as follows. First, How is the existence of SCC in Indonesia as set up in the Supreme Court Regulation No. 2 of 2015; and second, How is the concept of setting SCC in order to reform the national civil procedural law.

\section{Research Method}

The method used in this research is normative juridical research. Research with the perspective of legal/juridical focused on rules/ norms of Civil Procedures Law and comparative law through legal principles is the study of legal norms which are benchmarks to behave appropriately. In accordance with the method, the study was carried out on the norms and principles contained in the secondary data, which were found in the primary, secondary, and tertiary legal materials,.

\section{Discussion}

\section{Small Claims Court in Indonesia as a Country with the Civil Law System}

One of the important issues for a future development of the law including law enforcement in Indonesia is how to carry out the judicial authorities in accordance with the Indonesian Constitution of 1945 and Law No. 48 of

Ronald S Lumbuun, 2011, PerMA RI Wujud Kerancuan Antara Praktik Pembagian dan Pemusataan Kekuasaan, Jakarta: Raja Grafindo Persada, page 14.
2009 concerning Judicial Authority. ${ }^{4}$ The rule of law through the administration of justice functions as a means to ensure a fair process in order to produce decision that considers the interests (of justice) by both parties.

Law enforcement ran by court mechanisms and procedures that form is strongly influenced by the legal system adopted by a society or a country where the law applies. Most countries in the world adopt a civil law and common law. According to civil law enforcement system through the administration of justice, it is initiated by making legal regulations, sanctions, and so on according to the juridical pattern. The pattern of law enforcement with the given approach uses procedural law when associated with a material law enforced into civil law or criminal procedural law. The judge in the "run" judicial essentially checks reality that occurs through a certain process according to procedural law and punishing with current regulations by giving a verdict based on the material law. Examination of the fact until the decision is the stages of the formal legal process and formal orientation legistic and emphasize on how the law of the event run orderly which can ignore justice as a legal purpose. In addition, the law of goal attainment away with this approach is also caused by the use of the inquisitorial system of justice which is a system that gives judges a major role in directing and deciding cases. ${ }^{5}$

In practice, settlements of disputes in the courts use Civil Procedural Law, namely HIR/ RBg. Rules of court proceedings under the provisions HIR/RBg does not differentiate the course of the case investigation based on the size of the value of the case or any kind of dispute. HIR only distinguishes demands that justice be examined in the form of civil lawsuits (Article 118 HIR, $142 \mathrm{RBg}$ ) is more familiar with the lawsuit, and petition. Positive law does not regulate the

4 Fence M. Wantu, "Kendala Hakim Dalam Menciptakan Kepastian Hukum, Keadilan, dan Kemanfaatan di Peradilan Perdata", Mimbar Hukum Journal, Vol 25 No. 2, June 2013, Yogyakarta: Faculty of Law Universitas Gadjah Mada, page 206.

5 Anna Triningsih, "Pengadilan Sebagai Lembaga Penegakan Hukum", Jurnal Konstitusi, Vol 12, Number 1, March 2015, Jakarta: Mahkamah Konstitusi: page 145-146. 
civil procedure regarding the period in the settlement of civil disputes, either to simple or complex suit. In the implementation, the settlement often takes long time, the longer time occurs when there is a remedy proposal. This condition is not in line with the principle of fast, simple and low-cost justice as mandated by Law Number 48 Year 2009 concerning Judicial Authority.

For justice seekers who suffered a small loss but wanted to defend their rights in a dispute, the settlement out of court through the forum is not the right choice as well as the dispute settlement through the courts with the old procedures which are often considered to be disproportional to the value of the lawsuit which is relatively small. Therefore, the rules to check a small lawsuit is the major step in the reform of the Supreme Court of the civil justice system, as previously never known and pre-configured in HIR and RBg. By accelerating the means of dispute resolution, it will bring benefits to all sections of society to access a fast, simple and low cost justice.

In the Supreme Court Annual Report 2013 pages $80-86$, it can be concluded that the policy of access to justice ${ }^{6}$ include; first, policy changes of legal services for poor people in court: fee waiver, legal aid post, trial outside the courthouse; second, mediation; third, the integrated service identity rights law; and fourth, small claims settlement mechanism (Small Claims). In harmony with the policy of access to justice, required legal and judicial reform strategy more comprehensively and systematically aimed to facilitate the public to get justice one of them through the civil justice system reform is the introduction of simple procedures for lawsuit settlement.

The existence of SCC is intended to improve access to justice by providing fast, simple and low cost services. Allegedly high legal costs

6 See Anita Afriana \& Efa Laela Fakhriah, “A Fast Procedure as an Access to Justice in Order to Realize a Simple, Fast, and Low Cost Principle in Indonesia", Jurnal Dinamika Hukum, Vol 16 No 1, January 2014 Edition, Purwokerto: Faculty of Law Universitas Jenderal Soedirman, page 102 . can be a barrier obtaining justice, especially in a simple lawsuit. Indonesia SCC mechanism was adopted by the Supreme Court Regulation No. 2 of 2015.

Indeed, there are differences in achievement goals of law; civil law system promotes legal assurance in law enforcement, while on the other hand SCC was firstly issued in the common law system which emphasizes justice as an objective of the law, achieving justice through the 'adversarial', whereas in civil law with 'inquisitorial' through which the role of judges deciding cases. As provided in Supreme Court Regulation, the obligation for judges to take an active role in the form of giving a description of small claims procedural impartial to the parties; efforts for settling disputes peacefully, including suggestion to the parties for peace beyond the trial; guide the parties in the proof; and explain the legal remedies that can be taken of the parties.

It is believed that nowadays most countries do not purely apply the legal system (including Indonesia). Procedural Law is still needed as one of the important aspects of the law enforcement process. However, law enforcement of ansich certainly not be meaningful without considering the main purpose of the law, namely justice. Therefore, law enforcement should be fair or equal. To achieve this, various requirements are needed for law enforcement to run in accordance with the purpose of the law itself including accelerated time to resolve a case that is proportional to the damage suffered.

The author said that in its development, the achievement of the purpose of law does not necessarily mean to neglect the other laws. As we know that legal ideas (idee des recht) mentions the existence of three elements of legal ideas that must exist proportionally namely legal assurance, justice, and benefits. As stated by Gustav Radbruch related to law enforcement, the theory must fulfill these three elements. ${ }^{7}$ Therefore, the law enforcement pro-

7 Fence M. Wantu, “Anatomi dalam Penegakan Hukum oleh Hakim”, Jurnal Mimbar Hukum, Vol 19 No. 3, Octo- 
cess in Indonesia should be based on legal assurance, justice, and benefit. According to the theory of the value of justice (legal justice), the justice based on rule to the normative rules and applicable in the form of legislation, while the legislation is in the context of achieving the principle of legal assurance.

Since Supreme Court Regulation Number 2 Year 2015 enacts, it has been many small claims that has been settled, both the case of default or tort. ${ }^{8}$ Settling dispute in Cirebon and Central Jakarta District Court for example took 20-25 days since the case was filed. However, based on research, small claims were more decided by the courts located in the district or the city including to resolve dispute bank credit which debtor provides power to sell to creditors, while in the Class I District Court, in fact there are many lawsuits which can be categorized as small claims, but obstructed on the terms very limitedly arranged in Supreme Court Regulation Number 2 of 2015 including the parties having their legal domicile in a different area.

The existence of SCC were used to examine the small claims to build bridges between non-litigation dispute resolutions that do not give a binding effect with the settlement of litigation which gives more legal assurance, in order to obtain a fast, simple and low cost dispute settlement mechanism with the power binding decision. Therefore it can be concluded that the existence of SCC used in a simple lawsuit settlement is one form of effective law reform as necessary in accordance with the needs of a growing community.

Based on the results, countries implementing SCC have unequal application characteristics. In Singapore, Japan, and the Netherlands, SCC becomes an absolute competence of the court, but not with Australia. In japan and the Netherlands, the case investigation is done formally in accordance with the characteristics of the settlement of the dispute in court, but it is not the case in Singapore and Australia,

ber , 2007, Yogyakarta: Faculty of Law, Universitas Gadjah Mada, page 388.

8 Mahkamah Agung RI, available on www. Mahkamah agung.go.id/index.direktorimahkamahagung/Pengadilan Umum/Perdata, access on May 20 2016. where the settlement of disputes carried out with combination of litigation and non-litigation procedure. The similarities of Singapore, Japan, the Netherlands, and Australia that the SCC is intended to settle a lawsuit with little value, though in this case there are similarities in terms of nominal limit lawsuit. The authors can conclude that the application of SCC by a country adopted the characteristics of the applicable law in the country. For an example in Indonesia, the judge is bound by the principles of proce-dural law as a trial conducted openly, passive judges, etc so the examination of small claims is not conducted in private as practiced in Singapore.

\section{Regulation Concept of SCC in Indonesia in the framework of National Civil Procedural Law Reform}

One aspect in the development of national laws is the establishment of laws which are established by itself and it is a national law. One of the effort is by law reform.

As a country which stands based on civil law tradition, the basic principle as well as the purpose of the law is legal assurance. To achieve legal assurance, then constitution becomes the main source of law. Correspondingly, in the civil law system is developed so that the legal system becomes systematic by developing unification system. The basic characteristic of the civil law is the law obtain force binding because of the rules embodied in the form of legislation and systematically arranged in the codification or compilation. To achieve legal assurance, a regulation must be obvious and unambiguously set and impose limits on objects that basic regulates. Provisions that regulate explicitly and clearly applicable in general will provide legal assurance so that the formulation and regulation is clear. Indonesia's legal system as the former Dutch colony, which is civil law that oriented to the Continental European countries resulted Indonesia applying the Legisme principle and upholds the legislation as a source of supreme law.

Regarding to the age since it was firstly enacted until now, it has been more than a cen- 
tury. Thus the civil law regulation actually requires different adjustments and renewal law (law reform) that have relevance to the current judicial practice. The reform of civil procedural law settings is absolutely necessary in order to respond and accommodate the dynamics and legal developments that happened in society. In civil judicial practice, many current legal developments occured both on the legal institutions and procedures show that is not regulated in the civil procedural law.

Currently, Draft of Civil Procedural Law is being prepared. In the Draft of Civil Procedural Law, the provision of SCC (Small Claims Court) has not been set. On that basis, law reform must consider a number of aspects; philosophical, sociological, and juridical. Law reform through the establishment of constitution should not be done partially. It means that the civil procedural law settings that is both rigid and forced to be coherent, therefore coherency becomes important. Given the Draft of Civil Procedural Law is still in the drafting process, then Supreme Court Regulation as the basis for the implementation of SCC is used as a forum for dispute resolution as quickly as stipulated in Supreme Court Regulation Number 2 Year 2015. It is crucial in Indonesia and is intended to fill the legal vacuum as Article 79 of Law No. 14 of 1985 states: "The Supreme Court can further regulate the things that are necessary for the smooth administration of justice, if there are things not yet fully covered under this law."

As a comparison in countries that have implemented SCC both in countries with civil law and common law, SCC arrangement in the form of laws, such as implementation act are in the Netherlands and SCC Act in Singapore. Therefore expected SCC regulations can be inte-grated in the National Civil Procedural Law, so that it becomes unification in civil procedural law.

\section{Conclusion}

Arrangement of Small Claims Court (SCC) Regulation of Supreme Court No 2 of 2015 in Indonesia as a country with a civil law system accordance with the needs of the community. Settlement of disputes in Indonesia through the courts yet aims to achieve legal assurance should also be fair including short time in resolving the cases as the philosophical basis behind SCC namely justice.

The regulation of SCC in the form of Supreme Court Regulation Number 2 Year 2015 as temporary solution to get around is not invited the national civil procedural law in order to avoid a legal vacuum. In the future with the regulation of SCC in the statue of the National Civil Procedural Law is expected to obtain legal assurance through the rules, because justice as other legal purpose can be achieved by clear and definite setting.

\section{Suggestion}

Based on the author's analysis, there are some suggestions that can be given. First, the necessity to re-examine the requirements in completing a small claims including the same legal domicile for the parties to restrict the access of the parties to file small claims; second, for the interests of national civil procedural law reform, SCC substance should be integrated and arranged in the form of laws in a way enacting immediately the Draft of Civil Procedural Law in order to achieve a formal unification of civil law in Indonesia.

\section{References}

Afriana, Anita and Efa Laela Fakhriah. "A Fast Procedure as an Access to Justice in Order to Realize a Simple, Fast, and Low Cost Principle in Indonesia". Jurnal Dinamika Hukum, Vol. 16 No 1. January 2014. Purwokerto: Faculty of Law, Universitas Jenderal Soedirman;

Benny, R Riyanto, "Remodelling and Repositioning of Court's Mediation in Indonesia, Diponegoro Law Review, Vol. 1 No. 1, October 2016 Edition, Semarang: Faculty of Law, Universitas Diponegoro;

Lumbuun, S Ronald. 2011. PerMA RI Wujud Kerancuan Antara Praktik Pembagian dan Pemusataan Kekuasaan. Jakarta: Raja Grafindo Persada. 
Rajagukguk, Erman. "Peranan Hukum dalam Pembangunan Pada Era Globalisasi" Jurnal Hukum Bisnis. Vol. 6 No. II. Jakarta: Yayasan Pengembangan Hukum Bisnis;

Triningsih Anna. "Pengadilan Sebagai Lembaga Penegakan Hukum". Jurnal Konstitusi. Vol. 12 No. 1, March 2015. Jakarta: Mahkamah Konstitusi;

Wantu, Fence M. "Anatomi dalam Penegakan Hukum oleh Hakim". Jurnal Mimbar Hukum. Vol. 19 No. 3. October 2007 Edition. Yogyakarta: Faculty of Law Universitas Gadjah Mada;

...-.-., Perdata". Jurnal Mimbar Hukum. Vol 25 No. 2. June 2013. Yogyakarta: Faculty of Law. Universitas Gadjah Mada;

Wijayanta, Tata "Asas Kepastian Hukum, Keadilan, dan Kemanfaatan dalam Kaitannya Dengan Putusan Kepailitan Pengadilan $\mathrm{Ni}$ aga". Jurnal Dinamika Hukum. Vol. 14 No 2. May 2014. Purwokerto: Faculty of Law Universitas Jenderal Soedirman;

Mahkamah Agung RI. available on http//:www. mahkamahagung.go.id/index.direktorima hkamahagung/PengadilanUmum/Perdata. Access on May 20 2016. 